\title{
Civil society promoting government accountability for health equity in the Caribbean: The Healthy Caribbean Coalition
}

\author{
Trevor A. Hassell, ${ }^{1}$ Maisha T. Hutton, ${ }^{1}$ and D. Beverley Barnett ${ }^{1}$
}

Suggested citation Hassell TA, Hutton MT, Barnett DB. Civil society promoting government accountability for health equity in the Caribbean: The Healthy Caribbean Coalition. Rev Panam Salud Publica. 2020;44:e79. https://doi.org/10.26633/RPSP.2020.79

ABSTRACT Achieving health equity and addressing the social determinants of health are critical to attaining the health and health-related targets of the 2030 Agenda for Sustainable Development and its Sustainable Development Goals. Frameworks for health, including the Sustainable Health Agenda for the Americas 2018 - 2030, emphasize reduction of health inequities and "leaving no one behind" in national sustainable development. Health equity includes advancing universal health and the primary health care approach, with equitable access for all people to timely, quality, comprehensive, people- and community-centered services that do not cause impoverishment. Equally important, and a hallmark of good governance, is accountability for such advances. Governments have primary responsibility for reducing health inequities and must be held accountable for their policies and performance. Civil society has been recognized as a key partner in advancing sustainable and equitable national development. Effective accountability mechanisms should include civic engagement.

The Healthy Caribbean Coalition (HCC), the only Caribbean regional alliance of civil society organizations working to prevent and control noncommunicable diseases_a major health priority fueled by inequities — has played a significant role in holding governments accountable for advancing health equity. This case study examines factors contributing to the success of the HCC, highlighting work under its five strategic pillarsaccountability, advocacy, capacity development, communication, and sustainability-as well as challenges, lessons learned, and considerations for greater effectiveness.

Keywords Health equity; civil society; governance; non-communicable diseases; Caribbean region.

The Region of the Americas is one of the most inequitable in the world (1). The 2008 report of the World Health Organization (WHO) Commission on the Social Determinants of Health (SDH) highlighted the many stratifiers of equity and the impact that the environments and systems within which individuals are born, grow, live, work, and age can have on health (2). This context creates significant differentials in power, resources, opportunities, and health status among groups of people (2).

Both the 2030 Agenda for Sustainable Development and its Sustainable Development Goals (3) and the Sustainable Health Agenda for the Americas 2018-2030 (4) recognize theimportance of multisectoral, whole-of-government, whole-of-society, health-in-all-policies for tackling health and the SDH. They also highlight civil society as an essential partner in achieving equitable health outcomes that "leave no one behind," particularly persons in conditions of vulnerability and social exclusion.

Accountability can be defined as the obligation of powerholders - those who hold political, financial, or other forms of power, including government officials-to take responsibility for their actions (5). This type of accountability is a consequence of the implicit social compact between citizens and their delegated representatives in a democracy (5). It encompasses social

\footnotetext{
1 Healthy Caribbean Coalition, Bridgetown, Barbados. $\square$ Trevor Hassell, trevor.hassell@healthycaribbean.org
} 
accountability, an approach towards building accountability that relies on civic engagement-ordinary citizens and/or civil society organizations participating directly or indirectly in exacting accountability (5).

As the main duty-bearers for the progressive realization of the right to health, national governments must be held accountable for implementing policies and programs that enable the rights-holders-all people-to achieve the highest attainable standard of health. Civil society's service, advocacy, information-sharing, community engagement, and accountability ("watchdog") functions allow it to play a vital role in holding governments accountable for equity-based interventions.

The Healthy Caribbean Coalition (HCC) is a not-for-profit, regional alliance of over 100 civil society organizations (CSOs) working in noncommunicable disease (NCD) prevention and control in the Caribbean. It includes Member States of the Caribbean Community (CARICOM, https://caricom.org/), the main regional political integration entity, and was established in 2008 in response to the CARICOM Heads of State and Governments, (HoSG) 2007 Declaration of Port of Spain on NCDs (6). The HCC is the only Caribbean CSO NCD alliance. Its Secretariat is located in Barbados.

The HCC has been recognized regionally and internationally as a significant and influential advocate for NCD prevention and control and related issues (7). This illustrative case study aims to contribute to the research topic, "The role that civil society can play in promoting and contributing to government accountability for advancing health equity in limited-resource, vulnerable settings, such as the Caribbean," by showcasing selected actions and factors that have contributed to HCC's success. This case study also highlights challenges and lessons learned in the Caribbean and makes recommendations for greater effectiveness, which may be useful to CSOs in similar regions.

\section{HCC BACKGROUND}

Regional and global frameworks $(8-11)$ recognize the pivotal role of universal health (UH) in providing equitable access for all people to timely, quality, comprehensive, people- and community-centered services that do not cause impoverishment. UH includes the primary health care strategy that encompasses a responsive first-level of care and an integrated health services network. The Member States of the Pan American Health Organization (PAHO), the WHO Regional Office for the Americas, have endorsed resolutions to advance UH with integrated NCD reduction strategies.

Similar to NCD prevention and control, UH requires a multisectoral approach to address the SDH and promote a society-wide commitment to fostering health and well-being (8). Engagement with civil society brings benefits related to empowerment, service delivery, commitment, flexibility, participation in policy, and credibility (12), making it a critical partner in health and related accountability mechanisms that galvanize its much-vaunted "watchdog" functions.

The Caribbean is a region that comprises islands and mainland countries and territories of varying sizes, populations, and levels of development. It includes Small Island Developing States, as well as states classified as low-, middle-, and highincome by international financing institutions. Underpinning its functioning as a unique Caribbean regional CSO, the HCC vision of "vibrant, healthy Caribbean people free of chronic NCDs, achieving their fullest potential and contributing to equitable national and regional development" aligns with its values and guiding principles-empowerment of people, equity, inclusive partnerships, transparency and integrity, innovation, and accountability (13). This vision applies to all Caribbean countries and territories, regardless of characteristics.

\section{HCC INTERVENTIONS PROMOTING GOVERNMENT ACCOUNTABILITY}

While there are many facets to the HCC, its role in promoting and contributing to government accountability for advancing health equity is evident in its work from 2008 - 2018 (7) and through the information and communication products available on its website (https://www.healthycaribbean.org/). Selected HCC actions are presented here according to its five strategic pillars: accountability, advocacy, capacity development, communication, and sustainability (13).

\section{Accountability}

Caribbean governments are accountable to their people for the many commitments made at global, regional, and national health and health-related fora. An ongoing example is the HCC childhood obesity prevention (COP) accountability framework based on the HCC Civil Society Action Plan 2017 - 2021: Preventing Childhood Obesity in the Caribbean (14). It comprises (15):

- Regional and national political commitment mapping and achievement tracking through the COP Scorecard, an online database of national policies and programs that contribute to COP

- Capacity development for CSOs, youth, and persons living with NCDs through provision of sub-grants to CSOs for interventions, such as: establishment of the CSO COP Action Network; webinars; regional multi-stakeholder meetings; and collaborative development of communication materials and social media campaigns (7)

- Public engagement exemplified by the 2018 "Too Much Junk" campaign and online petition for children's healthier nutrition, and the "My Healthy Caribbean Schools" digital platform, which monitors obesogenic environments in Caribbean schools (7)

- Guidance on conflict of interest (CoI) identification and management, and on countering industry interference through meetings (16) and industry mapping and reporting

- High-level advocacy through open and closed letters to CARICOM HoSG and ministers, social media, attendance at high-level regional meetings, membership on regional working groups, and calls to action (7), including the 2019 Call for Urgent Action for healthy childhood nutrition policies (17).

HCC has emphasized the rights-based approach in its COP accountability initiatives, referencing the United Nations (UN) Convention on the Rights of the Child, and General Comment No. 15 of the UN Committee on the Rights of the Child (18), which specifically indicates that Member States should address obesity in children.

Evaluation and research are key elements of accountability, and the HCC has collaborated with the University of the West 
Indies in the 2016 evaluation of the CARICOM Port-of-Spain Declaration and the impact of the Barbados sugar-sweetened beverage tax (7).

\section{Advocacy}

By virtue of its work to date, the favorable reputation it has acquired, and the high degree of social interconnectedness that is characteristic of most Caribbean countries, the HCC has been able to gain access to individual, highly-level policymakers. Advocacy by the HCC not only addresses accountability, but also promotes multisectoral action to address the SDH and UH. It has identified and supported a number of NCD "champions"-persons with drive, passion, and expertisewho have participated in high-level meetings and international fora; presented statements and positions to CARICOM policymakers (including the Conference of HoSG) and public sector and civil society leaders; and interacted with national, regional, and international media (7). In 2015, the HCC convened a multi-stakeholder meeting on health systems strengthening, UH, and NCDs (19). In 2019, the Coalition developed a technical brief on UH (20) in preparation for the First UN High-level Meeting on Universal Health Coverage and presented it to the Caucus of CARICOM Ministers of Health at the 2019 World Health Assembly.

Early on, the HCC recognized the importance of the commercial determinants of health and the need to engage and collaborate with the private sector, while identifying and managing CoI. In 2015, HCC convened a Caribbean private sector forum, assessed that sector's contribution to NCD reduction, and developed a framework to strengthen relevant action (21). These efforts to work with industry sought to strengthen prohealth business practices and find win-win solutions.

\section{Capacity development}

The capacity of civil society actors plays a key role in successful social accountability. The level of organization of CSOs, the breadth of their membership, their technical and advocacy skills, their capacity to mobilize and effectively use media, their legitimacy and representativity, and their level of responsiveness and accountability to their own members are all central to the success of social accountability activities. In many contexts, efforts to promote an enabling environment for civil society and to build the capacity (both organizational and technical) of CSOs are required (5).

CSOs in the Caribbean vary in size and capacity, and capacity development is a cornerstone of HCC activity (7). HCC has involved CSOs-at no cost to the organizations-in regional multi-stakeholder meetings and webinars, and has provided sub-grants and guidance in project development and execution (7). These initiatives have resulted in improved CSO capacity in advocacy, monitoring government actions, communication, health literacy, project management, and implementation of evidence-based interventions (7). Also, by including public sector representatives in these exercises and undertaking specific capacity development interventions for multisectoral NCD commissions, HCC has sensitized various sectors to the health impacts of their policies and programs. These interventions have highlighted the importance of the SDH, the health-in-allpolicies approach, and reducing health inequities.
HCC has also emphasized capacity development for individuals in vulnerable conditions, including youth and persons living with NCDs. In 2014, HCC established the Youth4NCDs program (7), which aims to empower young advocates. In 2019, HCC designated "Youth Voices" and "Our Views, Our Voices" technical advisors, along with related advocacy training (https://www.healthycaribbean.org/our-views-our-voices/).

\section{Communication}

HCC communication and information products, available from its website and social media platforms, have been recognized as major successes, especially the weekly online "News Roundup" (7). This method of communicating and disseminating information is ideally suited to its various audiences, including its geographically dispersed CSO members; government sectors across the region; other national, regional, and international partners; and the general public. The products promote evidence and multisectorality, and include reports, infographics, technical briefs targeting CARICOM governments and other stakeholders, and policy briefs on topics such as climate change, NCDs, and Small Island Developing States; NCDs and trade policy; and nutrition policies for children's health.

\section{Sustainability}

Resource mobilization is critical for the HCC. Member CSOs pay no fees and the HCC receives no subventions from national or regional authorities, so it is wholly dependent on external support.

HCC is a trusted partner of Ministries of Health and regional and international intergovernmental and nongovernmental organizations. It has received support from PAHO, CARICOM, the Caribbean Development Bank, the NCD Alliance (NCDA), Global Health Advocacy Incubator, World Diabetes Foundation, and the Australian Direct Aid Program, among others (7). HCC's partnerships with Sagicor Life Incorporated (Barbados) and CIBC/FirstCaribbean International ComTrust Foundationboth pro-health private sector entities (PSEs) — provide ongoing support for the HCC Secretariat and demonstrate good practices in PSE engagement.

In the context of PSE engagement, the HCC CoI guidance is a groundbreaking and important accountability initiative given the region's close social interconnections and the limited resource mobilization typical of Small Island Developing States. The emphasis placed on the links among CoI identification and management, accountability, and improved governance promotes health equity in the region.

As an acknowledged leader in NCD prevention and control in the Caribbean, HCC enjoys invited representation on WHO expert panels, the NCDA Board, and at international meetings (7). It has received many accolades (7), including the Sharjah Award for Excellence in NCD Civil Society Action in 2017 and 2020, and the UN Interagency Task Force on NCDs Award for Outstanding Non-State Actor in 2018.

\section{DISCUSSION}

Despite difficulties in clearly identifying the impact of its work, due to the nature of the organization, the HCC has 
undoubtedly demonstrated its value in the Caribbean (7). The HCC has been a major force in advocating for a more prominent place for health in the region's political and development agendas; in highlighting the virtue and value of accountability; and in promoting the need for an equity lens in health (7).

Notwithstanding its exemplary role in promoting governments' accountability for advancing health equity, the HCC faces several challenges, some of which are intrinsic to its geographical location and the dispersed nature of its member organizations. Like most CSOs working on health in the Caribbean, HCC encounters challenges to mobilizing adequate human and financial resources in this resource-limited environment (7). There are also major challenges in devising approaches to strengthen the governance and operational capacities of its member CSOs and in securing a voice in the Caribbean's high-level councils. These challenges impede the HCC's efforts to promote collective action on NCDs, represent the NCD community, and emphasize the need and mechanisms for accountability. Finally, the HCC faces the absence of disaggregated data for use in establishing baselines, informing claims of inequality and inequity, and measuring progress. Without measuring inequalities, there can be no quantifiable focus on equity (22).

Over 12 years of experience, the most important lesson learned by the HCC is realizing and operationalizing the power of networks and partnerships at all levels of government and society. The importance of high-level advocacy by well-placed champions is increasingly evident, as is the imperative of hearing, engaging, and promoting the voices of youth and persons living with NCDs. The validity of and necessity for stimulating the public to hold policymakers accountable are central aspects of the HCC philosophy, as is the strategic value of using effective entry points, such as COP, to highlight equity concerns.

There are ample opportunities for expanding HCC partnerships, especially with academia and similar bodies, to: provide a strong voice for health data collection and disaggregation by socioeconomic stratifiers; engage actors beyond the health sector; further strengthen its member CSOs; continue developing accountability frameworks; and bolster promotion of and support for multisectorality-whole-of-government and whole-of-society-with an emphasis on CoI identification and management.

\section{Conclusions}

The HCC's emphasis on accountability, relentless highlevel advocacy, inclusive and targeted capacity development, audience-oriented information and communication products, and innovative and strategic resource mobilization has secured its wide recognition as a key player in promoting and contributing to government accountability for advancing health equity. Though the HCC focuses on NCD prevention and control, its strategies and methods-adjusted as appropriate-may be applicable to other priority health issues in the Caribbean and beyond.

Author contributions. All authors contributed to the data and analysis. DBB wrote the initial draft of the paper, all authors reviewed and contributed to subsequent drafts. All authors reviewed and approved the final version.

Acknowledgements. George Alleyne, Patron, Healthy Caribbean Coalition, reviewed an early draft of the paper and provided input.

Funding. Funders of the Healthy Caribbean Coalition had no role in the study design, data collection or analysis, decision to publish, or preparation of the manuscript.

\section{Conflicts of interest: None declared.}

Disclaimer. Authors hold sole responsibility for the views expressed in the manuscript, which may not necessarily reflect the opinion or policy of the RPSP/PAJPH and/or PAHO.

\section{REFERENCES}

1. Pan American Health Organization. Health in the Americas, 2017. Summary: Regional outlook and country profiles. Washington, DC: PAHO; 2017. Available from: https://bit.ly/2TRbaKs Accessed 14 March 2020.

2. Commission on Social Determinants of Health. Closing the gap in a generation: Health equity through action on the social determinants of health. Geneva: World Health Organization; 2008. Available from: https://bit.ly/32uoilh Accessed 26 February 2020.

3. United Nations. Transforming our world: The 2030 agenda for sustainable development. Document A/RES/70/1. New York: UN; 2015. Available from: https:/ / bit.ly/2VkyQbw Accessed 26 February 2020.

4. Pan American Health Organization. The Sustainable Health Agenda for the Americas 2018-2030: A call to action for health and well-being in the region. Document CSP29/6, Rev.3. Washington, DC: PAHO; 2017. Available from: https://bit.ly/2T4T1sB Accessed 26 February 2020.

5. Malena C, Forster R, Singh J. The role of civil society in holding government accountable: A perspective from the World Bank on the concept and emerging practice of "social accountability." New York: World Bank; 2004. Available from: https://bit.ly/2VQd930 Accessed 29 April 2020.
6. Caribbean Community. Declaration of Port of Spain: Uniting to stop the epidemic of chronic NCDs. Georgetown, Guyana: CARICOM; 2007. Available from: https://bit.ly/2UtEbv3 Accessed 23 March 2020.

7. Healthy Caribbean Coalition. Celebrating 10 years of a civil society regional response to the prevention and control of NCDs in the Caribbean. Bridgetown, Barbados: HCC; 2018. Available from: https:/ / bit.ly/2VFwqEp Accessed 3 March 2020.

8. Pan American Health Organization. Strategy for universal access to health and universal health coverage. Document CD53/5, Rev.2. Washington, DC: PAHO; 2014. Available from: https://bit. ly/2QF8AW8 Accessed 23 March 2020.

9. World Health Organization, United Children's Fund. Declaration of Astana. Proceedings of the Global Conference on Primary Health Care: From Alma-Ata towards universal health coverage and the Sustainable Development Goals, Astana, Kazakhstan, 25 - 26 October 2018. WHO, UNICEF; 2018. Available from: https://bit. ly/38fSHeS Accessed 1 March 2020.

10. Pan American Health Organization. Universal health in the 21st century: 40 years of Alma Ata. Report of the High-level Commission. Washington, DC: PAHO; 2019. Available from: https://bit. ly/32ywQOc Accessed 27 February 2020. 
11. Pan American Health Organization. Just societies: Health equity and dignified lives. Report of the Commission of the Pan American Health Organization on Equity and Health Inequalities in the Americas. Washington, DC: PAHO; 2019. Available from: https:// bit.ly/39H7nVA Accessed 27 February 2020.

12. Greer SL, Wismar M, Kosinska M. What is civil society and what can it do for health? In: Greer SL, Wismar M, Pastorino G, et al., eds. Civil society and health: Contributions and potential. Copenhagen: European Observatory on Health Systems and Policies; 2017. Available from: https://www.ncbi.nlm.nih.gov/books/NBK459047/ Accessed 30 April 2020.

13. Healthy Caribbean Coalition. Strategic Plan 2017 - 2021: Enabling Caribbean civil society's contribution to national, regional, and global action for NCD prevention and control. Bridgetown, Barbados: HCC; 2017. Available from: https://bit.ly/3amam5L Accessed 27 February 2020.

14. Healthy Caribbean Coalition. Civil society action plan 2017 - 2021: Preventing childhood obesity in the Caribbean. Bridgetown, Barbados: HCC; 2017. Available from: https://bit.ly/2IdURRk Accessed 3 March 2020.

15. NCD Alliance. NCD Atlas 2020 - Bridging the gap on NCDs through civil society action: Initiatives of regional and national NCD alliances. Geneva: NCDA; 2020. Available from: https://bit. ly/2VUhTF3 Accessed 8 March 2020.

16. Healthy Caribbean Coalition. Managing conflict of interest for NCD prevention and control in the Caribbean. Meeting Report. Bridgetown, Barbados: HCC; 2019. Available from: https://bit. ly/3dnBR1k Accessed 23 March 2020.

17. Healthy Caribbean Coalition. A civil society call to urgent action for the Caribbean region to accelerate nutrition policies for the creation of healthy environments for Caribbean children. Bridgetown, Barbados: HCC; September 2019. Available from: https:/ / bit. ly/2ZMjONY Accessed 1 May 2020.
18. United Nations Committee on the Rights of the Child. General comment No. 15 on the right of the child to the enjoyment of the highest attainable standard of health. Article 24, paragraph 42. Document CRC/C/GC/15. New York: UN; 17 April 2013. Available from: https://bit.ly/2VXDBrD Accessed 3 March 2020.

19. Healthy Caribbean Coalition. Strengthening health systems, supporting NCD action: Caribbean civil society health systems strengthening meeting. Meeting report and CSO HSS Statement of Commitment. Bridgetown, Barbados: HCC; 2015. Available from: https://bit.ly/38Kb5gc Accessed 10 March 2020.

20. Healthy Caribbean Coalition. First UN High-level Meeting on Universal Health Coverage: Technical brief for CARICOM countries: a contribution from civil society. Bridgetown, Barbados: HCC; 2019. Available from: https:/ / bit.ly/2W9dazF Accessed 9 March 2020.

21. Healthy Caribbean Coalition. The Caribbean private sector response to NCDs: A situation analysis and framework for action. Bridgetown, Barbados: HCC; 2015. Available from: https://bit. ly/32PMpBp Accessed 1 March 2020.

22. Pan American Health Organization. High-level meeting on information systems for health: Advancing public health in the Caribbean region. Report of meeting 7-8 November 2016, Kingston, Jamaica. Washington, DC: PAHO; 2017. Available from: https://bit. ly/2ZOUXck Accessed 30 May 2020.

Manuscript received on 27 March 2020. Revised version accepted for publication on 14 May 2020.

\section{Papel de la sociedad civil en la promoción de la rendición de cuentas de los gobiernos en materia de equidad en salud en el Caribe: la Coalición Caribe Saludable}

RESUMEN

Palabras clave
Alcanzar la equidad en salud y abordar los determinantes sociales de la salud son aspectos fundamentales para alcanzar las metas en materia de salud y relacionadas con la salud de la Agenda para el Desarrollo Sostenible 2030 y sus Objetivos de Desarrollo Sostenible. Los marcos de referencia para la salud, como la Agenda de Salud Sostenible para las Américas 2018-2030, hacen hincapié en la reducción de las desigualdades en salud y en "no dejar a nadie atrás" en el desarrollo sostenible a nivel nacional. La equidad en salud incluye la promoción de la salud universal y el enfoque de atención primaria de la salud, con un acceso equitativo de todas las personas a servicios de salud oportunos, de calidad, integrales y centrados en las personas y la comunidad que no ocasionen empobrecimiento. La rendición de cuentas por esos avances es igualmente importante, y un signo distintivo de una gobernanza adecuada. Los gobiernos tienen la responsabilidad primordial de reducir las desigualdades en salud y deben rendir cuentas de sus políticas y su desempeño. La sociedad civil es una parte interesada fundamental para promover un desarrollo nacional sostenible y equitativo, y debe formar parte de los mecanismos eficaces de rendición de cuentas.

La Coalición Caribe Saludable —la única alianza regional del Caribe de organizaciones de la sociedad civil dedicada a prevenir y controlar las enfermedades no transmisibles, una prioridad sanitaria importante acrecentada por las desigualdades - ha desempeñado un papel importante en hacer que los gobiernos rindan cuentas de la promoción de la equidad en salud. En este estudio se examinan los factores que han contribuido al éxito de la Coalición Caribe Saludable, con énfasis en la labor realizada en el marco de sus cinco pilares estratégicos — rendición de cuentas, promoción de la causa, desarrollo de capacidad, comunicación y sostenibilidad - así como los retos, las enseñanzas extraídas y otras consideraciones para lograr una mayor eficacia.

Equidad en salud; sociedad civil; gobernanza; enfermedades no transmisibles; Región del Caribe. 